\title{
Effect of Different Amendments on Nitrogen Conservation During Simulated Composting
}

\author{
Li Danyang, Qi Chuanren, Wei Yanan, Li Guoxue and Yuan Jing \\ College of Resource and Environment, China Agricultural University, Beijing 100193, China
}

\begin{abstract}
The objectives of this study were to evaluate the effects of different dosages of three amendments- peat, superphosphate, mixture of $\mathrm{Mg}(\mathrm{OH})_{2}+\mathrm{H}_{3} \mathrm{PO}_{4}$ ((Magnesium Hydroxide and Phosphorus Acid) on $\mathrm{N}$ (Nitrogen) conservation. The simulated composting experiment was carried out in a constant temperature water bath with pig manure and corn straw. The results showed that the ammonia volatilization could be inhibited to some extent under the treatments with fixing agents. Under the same simulated composting conditions, the nitrogen fixation effect of the three kinds of fixatives with the same proportion was as follows: $\mathrm{Mg}(\mathrm{OH})_{2}+\mathrm{H}_{3} \mathrm{PO}_{4}>$ superphosphate $>$ peat. The fixation effect of $\mathrm{N}$ increased with the increase of the additives. The $\mathrm{N}$ fixation rate of $\mathrm{Mg}(\mathrm{OH})_{2}+\mathrm{H}_{3} \mathrm{PO}_{4}$ treatment was up to $66 \%$. Compared with the $\mathrm{CK}$ (Control Group), the amount of cumulative ammonia emission decreased by $90.3 \%$ and the TN (Total Nitrogen) content increased by $39.31 \%$ in this treatment. Compared with other two kinds of fixing agents, $\mathrm{Mg}(\mathrm{OH})_{2}+\mathrm{H}_{3} \mathrm{PO}_{4}$ treatment could not only control $\mathrm{N}$ loss in composting process, improve the $\mathrm{N}$ nutrient content of compost products, but also could increase $\mathrm{P}$ (Phosphorus) and $\mathrm{Mg}$ (Magnesium) nutrients. Therefore, it had more popularization value and application prospect.
\end{abstract}

Key words: Simulated composting, amendment, effect of N conservation.

\section{Introduction}

Composting is one of the most important methods to realize the recycling and utilization of waste resources such as straw and livestock manure [1]. However, the $\mathrm{N}$ (Nitrogen) loss in the composting process could not only reduce the nutrient content and fertilizer efficiency of fertilizer, but also aggravate the environmental pollution [2] and become an important source of fine particulate matter (for example, PM2.5) in the air [3]. At present, there are two main methods to control $\mathrm{N}$ loss: the one is to change the process conditions, such as appropriate $\mathrm{C} / \mathrm{N}$ (Carbon/Nitrogen), $\mathrm{pH}$, temperature, MC (Moisture Content), ventilation, turnover frequency, etc. [4]. The other is to use additives in the composting process. The common are physical, chemical and biological amendments, such as zeolite, biochar, metal salts, phosphates, N-fixing bacteria, EM (Effective

Corresponding author: Li Guoxue, master, professor, research fields: solid waste treatment and resource utilization.
Microorganisms) bacteria, etc.. In previous work, different Mg (Magnesium) and P (Phosphorus) salts were used as $\mathrm{N}$-fixing additives for struvite crystallization process. This process could decrease ammonia emission by generating struvite crystal $\left(\mathrm{MgNH}_{4} \mathrm{PO}_{4} \cdot 6 \mathrm{H}_{2} \mathrm{O}\right)$, which was a poor water soluble, high-quality, slow-release fertilizer [5-7]. Several scholars have studied the effect of a certain type of additive on $\mathrm{N}$ morphological transformation in the composting process [8, 9], yet with lack of comprehensive comparative evaluation and analysis of several additives.

Based on the rule of $\mathrm{N}$ loss in composting process, the objectives of this study were to evaluate the effect of three amendments [peat, superphosphate and $\mathrm{Mg}(\mathrm{OH})_{2}+\mathrm{H}_{3} \mathrm{PO}_{4}$ (Magnesium Hydroxide and Phosphorus Acid)] at different dosages on $\mathrm{N}$ conservation during simulated composting. The best kind and amount of $\mathrm{N}$ fixation material were selected to provide a reliable $\mathrm{N}$ loss control scheme for the development of composting. 


\section{Material and Methods}

\subsection{Raw Materials}

In this experiment, fresh pig manure and corn straw were used as compost materials. The pig manure was taken from the Sujiatuo pig farm in Haidian district, Beijing. The corn straw was taken from the experimental field in the Science Park of China Agricultural University, which was cut into about 1 $\mathrm{cm}$ fragments. The basic properties of raw materials were shown in Table 1. Peat, superphosphate, $\mathrm{Mg}(\mathrm{OH})_{2}+\mathrm{H}_{3} \mathrm{PO}_{4}$ were chemically pure, which were added to the materials for composting.

\subsection{Experimental Design and Sample Collection}

Urea (pure $\mathrm{C}$ and $\mathrm{N}$ source) was used to adjust $\mathrm{C} / \mathrm{N}$ of the raw materials to 20. The $\mathrm{N}$ fixatives-peat, superphosphate and $\mathrm{Mg}(\mathrm{OH})_{2}+\mathrm{H}_{3} \mathrm{PO}_{4}$ were named $\mathrm{A}$,
$\mathrm{B}$, and $\mathrm{C}$ and were also compared to a CK (Control Group) without additive. Three replicates were set for each treatment and the experimental design was shown in Table 2. Urea was dissolved in the aqueous solution completely, and then spread and mixed in raw materials evenly. The MC of the materials was controlled to $70 \%$. Composting sealed fermentation bottles with capacity of $1 \mathrm{~L}$ were placed in a thermostatic water bath with adjustable temperature, and the temperature control simulated the outdoor composting temperature. Forced mechanical intermittent ventilation was adopted, and the ventilation rate was controlled at about $0.1 \mathrm{~m}^{3} /\left(\mathrm{min} \cdot \mathrm{m}^{3}\right)$ for half an hour with a one-hour interval. The test lasted for 10 days and the test apparatus was shown in Fig. 1.

During the experiment, Samples of approximately $100 \mathrm{~g}$ were taken at $0,3,6,8$ and 10 days, respectively. Accurate weighing was performed before and after

Table 1 The properties of raw materials.

\begin{tabular}{lll}
\hline Property & Pig manure & Cornstalk \\
\hline TOC $(\mathrm{g} / \mathrm{kg} \mathrm{DM})$ & $370 \pm 3.18$ & $430 \pm 3.32$ \\
$\mathrm{TN}(\mathrm{g} / \mathrm{kg} \mathrm{DM})$ & $19.3 \pm 0.62$ & $11.1 \pm 0.04$ \\
$\mathrm{NH}_{4}^{+}-\mathrm{N}(\mathrm{g} / \mathrm{kg} \mathrm{DM})$ & $0.97 \pm 0.01$ & -- \\
$\mathrm{EC}(\mathrm{ms} / \mathrm{cm})$ & $3.78 \pm 0.14$ & $2.15 \pm 0.09$ \\
$\mathrm{C} / \mathrm{N}$ & $19 \pm 0.49$ & $39 \pm 0.36$ \\
$\mathrm{pH}$ & $8.5 \pm 0.22$ & $7.7 \pm 0.34$ \\
$\mathrm{MC}(\%)$ & $72 \pm 0.63$ & $23 \pm 0.21$ \\
\hline
\end{tabular}

DM: dry matter; TOC: total organic carbon; TN: total nitrogen; $\mathrm{NH}_{4}{ }^{+}-\mathrm{N}$ : ammonium nitrogen; EC: electrical conductivity; --, undetected.

Table 2 The dry weight proportion of composting materials and the dosage of adsorbents.

\begin{tabular}{|c|c|c|c|c|c|c|c|}
\hline Treatments & Pig manure (\%) & Cornstalk (\%) & Urea (\%) & Additive (\%) & MC (\%) & $\mathrm{C} / \mathrm{N}$ & Type of additive \\
\hline$\overline{\mathrm{CK}}$ & 16.67 & 12.90 & 0.43 & $0^{\mathrm{a}}$ & 70 & 20 & -- \\
\hline A1 & 53.43 & 41.35 & 1.38 & 3.85 & 70 & 20 & \multirow{4}{*}{ Peat } \\
\hline $\mathrm{A} 2$ & 52.42 & 40.57 & 1.35 & 5.66 & 70 & 20 & \\
\hline A3 & 51.45 & 39.81 & 1.33 & 7.41 & 70 & 20 & \\
\hline A4 & 50.51 & 39.09 & 1.30 & 9.09 & 70 & 20 & \\
\hline B1 & 53.43 & 41.35 & 1.38 & 3.85 & 70 & 20 & \multirow{5}{*}{ Superphosphate } \\
\hline B2 & 52.42 & 40.57 & 1.35 & 5.66 & 70 & 20 & \\
\hline B3 & 51.45 & 39.81 & 1.33 & 7.41 & 70 & 20 & \\
\hline B4 & 50.51 & 39.09 & 1.30 & 9.09 & 70 & 20 & \\
\hline $\mathrm{C} 1$ & 53.43 & 41.35 & 1.38 & $3.85(1: 1)^{b}$ & 70 & 20 & \\
\hline $\mathrm{C} 2$ & 51.45 & 39.81 & 1.33 & $7.41(1: 2)$ & 70 & 20 & \multirow[t]{2}{*}{$\mathrm{Mg}(\mathrm{OH})_{2}+\mathrm{H}_{3} \mathrm{PO}_{4}$} \\
\hline $\mathrm{C} 3$ & 50.51 & 39.09 & 1.30 & $9.09(1: 3)$ & 70 & 20 & \\
\hline
\end{tabular}

${ }^{\mathrm{a}}$ Dry weight ratio; ${ }^{\mathrm{b}}$ Molar ratio of $\mathrm{Mg}(\mathrm{OH})_{2}$ to $\mathrm{H}_{3} \mathrm{PO}_{4}$. 




Fig. 1 Structure of simulated composting equipment.

1: pump; 2: filter humidifier; 3: constant temperature water bath; 4: compost materials; 5: 2\% boric acid; 6: catheter.

each sampling to calculate the material balance. The sample was divided into two parts: one part was fresh sample, which was used to measure water content and other water-soluble indexes; the other part was air-dried and ground to pass through a $0.1 \mathrm{~mm}$ sieve as a dry sample. The MC of the compost was calculated according to the MC of the sample, which was used as the basis for supplementing the $\mathrm{MC}$ and keeping it $70 \%$. The $\mathrm{N}$ fixation rate was calculated and the $\mathrm{N}$ control effect of the fixatives in composting process was studied.

\subsection{Analytical Methods and Calculations}

The MC of the samples was determined by drying at $105{ }^{\circ} \mathrm{C}$ for $8 \mathrm{~h}$. TN content was measured by an elemental analyzer (Elementar vario MACRO cube, Germany). $\mathrm{NH}_{4}{ }^{+}-\mathrm{N}$ was extracted with $2 \mathrm{M} \mathrm{KCl} \mathrm{(1:20)}$ and was analyzed by a segmented flow analyzer (Technicon Autoanalyzer II system, Germany). The $\mathrm{NH}_{3}$ was absorbed by a washing bottle with boric acid (2\%) and then titrated using $0.1 \mathrm{M} \mathrm{H}_{2} \mathrm{SO}_{4}$. Calculation method of $\mathrm{N}$ loss rate and fixation rate is:

$\mathrm{N}$ loss rate $X=$

$$
\left(M_{0} \times N_{0}-M_{1} \times N_{1}\right) /\left(M_{0} \times N_{0}\right) \times 100 \%
$$

$\mathrm{N}$ fixation rate $Y=\left(X_{\mathrm{CK}}-X_{\text {Treatment }}\right) / X_{\mathrm{CK}} \times 100 \%$ where $\mathrm{M}_{0}$ is the initial weight of materials, dry weight, $\mathrm{g} ; M_{1}$ is the weight of the sample material on day 10 , dry weight, $\mathrm{g} ; N_{0}$ is the $\mathrm{TN}$ content in the initial material, $\% ; N_{1}$ is the $\mathrm{TN}$ content of the sample material on day $10, \%$.

All data were analyzed using One-Way Analysis of
Variance (ANOVA). SPSS 17 for Windows was used for all statistical analysis.

\section{Results and Discussion}

\subsection{Temperature}

The test temperature was simulated to the composting temperature outdoor. Constant temperature water bath control was adopted in three stages of heating, high temperature and cooling. The high temperature phase lasted for five days $\left(50{ }^{\circ} \mathrm{C}\right.$ or higher) and the temperature change was shown in Fig. 2.

\subsection{N Changes during Simulated Composting}

\subsubsection{Ammonia Emission}

As could be seen from Fig. 3, only a small amount of ammonia gas was released during the 0-3 days of the heating period, and the ammonia emission amount accounted for $3.11 \%-14.91 \%$ of the total emission amount (Table 3 ). The high temperature period was

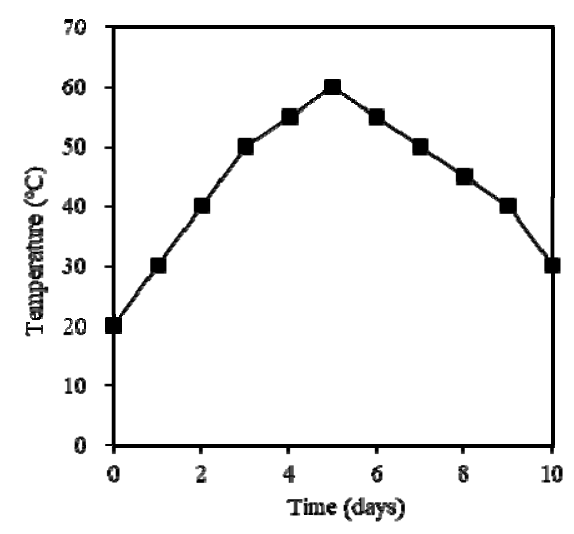

Fig. 2 The temperature changes during composting. 

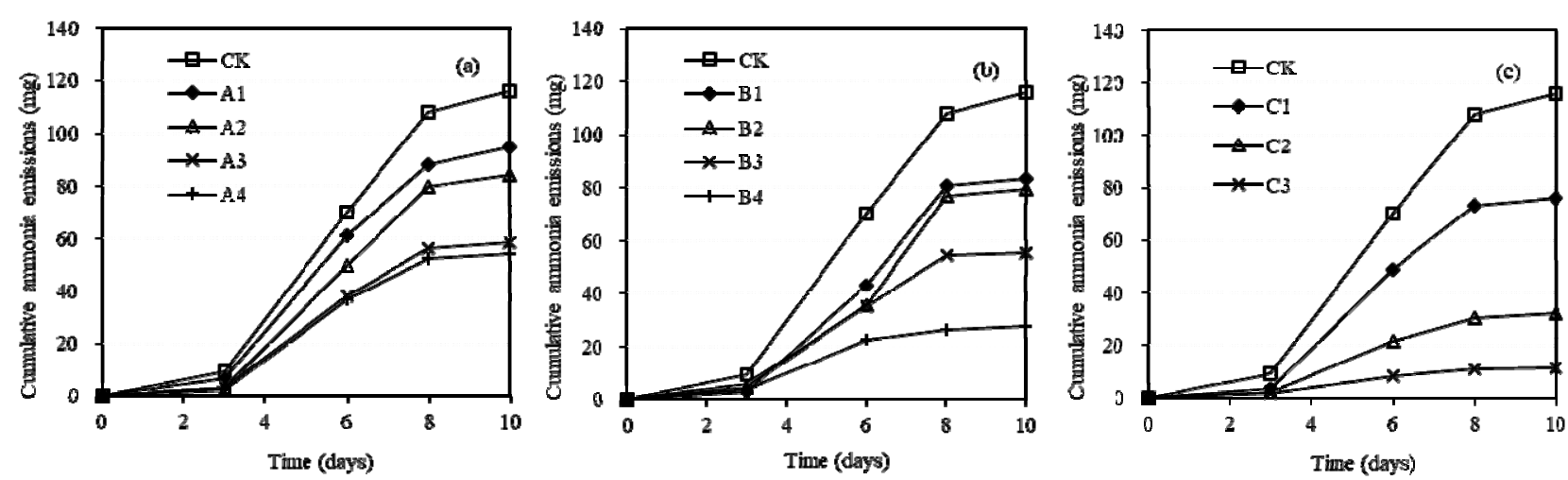

Fig. 3 Cumulative ammonia emissions of different treatments. (a) peat, (b) superphosphate, $(\mathrm{c}) \mathbf{M g}(\mathbf{O H})_{2}+\mathbf{H}_{3} \mathbf{P O}_{4}$.

A1: 3.85\% peat; A2: 5.66\% peat; A3: 7.41\% peat; A4: 9.09\% peat; B1: 3.85\% superphosphate; B2: 5.66\% superphosphate; B3: 7.41\% superphosphate; B4: $9.09 \%$ superphosphate; $\mathrm{C} 1: \quad 3.85 \% \quad \mathrm{Mg}(\mathrm{OH})_{2}+\mathrm{H}_{3} \mathrm{PO}_{4} ; \quad \mathrm{C} 2: \quad 7.41 \% \quad \mathrm{Mg}(\mathrm{OH})_{2}+\mathrm{H}_{3} \mathrm{PO}_{4} ; \quad \mathrm{C} 3: \quad 9.09 \%$ $\mathrm{Mg}(\mathrm{OH})_{2}+\mathrm{H}_{3} \mathrm{PO}_{4}$.

Table 3 The proportion of ammonia emission amount in each phase to the total emission amount.

\begin{tabular}{lllll}
\hline \multirow{2}{*}{ Treatments } & \multicolumn{3}{c}{ Proportion (\%) } \\
\cline { 2 - 5 } CK & $0-3 \mathrm{~d}$ & $3-6 \mathrm{~d}$ & $6-8 \mathrm{~d}$ & $8-10 \mathrm{~d}$ \\
$\mathrm{~A} 1$ & 8.10 & 52.29 & 32.72 & 6.89 \\
$\mathrm{~A} 2$ & 7.32 & 57.30 & 28.64 & 6.74 \\
$\mathrm{~A} 3$ & 3.98 & 55.05 & 35.87 & 5.09 \\
$\mathrm{~A} 4$ & 5.81 & 58.85 & 30.98 & 4.36 \\
$\mathrm{~B} 1$ & 3.88 & 64.21 & 28.40 & 5.19 \\
B2 & 3.11 & 48.19 & 45.32 & 3.38 \\
B3 & 5.27 & 39.42 & 51.58 & 3.73 \\
B4 & 10.17 & 53.07 & 35.53 & 1.22 \\
C1 & 12.09 & 69.24 & 13.19 & 5.48 \\
C2 & 4.38 & 60.40 & 31.54 & 3.67 \\
C3 & 6.60 & 60.12 & 27.53 & 5.74 \\
\hline
\end{tabular}

the peak period of ammonia release, and the ammonia release amount was significantly increased in 3-6 days. The cumulative ammonia emission amount accounted for $39.42 \%-69.24 \%$ of the total amount. During 6-8 days, with the gradual decrease of composting temperature, the ammonia amount decreased, and the cumulative ammonia amount accounted for $13.19 \%-51.58 \%$ of the total release amount. After 8 days, ammonia release decreased and stabilized, accounting for only $1.22 \%-6.89 \%$ of the total amount. Ammonia emissions decreased gradually with the increase of the amount of fixative (Fig. 3), indicating that the greater the proportion of fixative within the range of the experimental design, the better the fixation effect on ammonia $\mathrm{N}$.

Compared with the $\mathrm{CK}$, the three fixatives all controlled the ammonia volatilization to different extent. Under the same addition ratio, the $\mathrm{Mg}(\mathrm{OH})_{2}+\mathrm{H}_{3} \mathrm{PO}_{4}$ treatment had the highest reduction rate, which was $90.28 \%$ compared with the control. The treatment of superphosphate was the next $(76.13 \%)$, the last one was the peat treatment $(53.44 \%)$.

The effect of ammonia emission reduction was different due to the different fixation principles of $\mathrm{N}$ fixing agents. Peat was the remains of marsh plants, with organic matter content of more than $30 \%$. The $\mathrm{pH}$ ranged from 5.0 to 6.9 , showing slightly acidic, 
which could absorb and fix ammonia emission to some extent. At the same time, its own nutrients could improve the fertility of compost products $[10,11]$. The main components of superphosphate were $\mathrm{Ca}\left(\mathrm{H}_{2} \mathrm{PO}_{4}\right)_{2} \cdot \mathrm{H}_{2} \mathrm{O}$ (Monocalcium Phosphate Monohydrate), containing $14 \%-20 \%$ of available $\mathrm{P}$ $\left(\mathrm{P}_{2} \mathrm{O}_{5}\right), 40 \%-50 \%$ of calcium sulfate, and $3.5 \%-5 \%$ of free sulfuric acid and phosphoric acid. Studies have shown that the $\mathrm{pH}$ value of its saturated solution was 1.48, which was acidic [12]. By adding superphosphate, ammonia volatilization could be reduced by reducing the $\mathrm{pH}$ value of compost materials, and the following reactions may occur to generate relatively stable acidic ammonium phosphate or ammonium sulfate, so as to fix $\mathrm{NH}_{4}{ }^{+}-\mathrm{N}$ and reduce the loss of $\mathrm{N}$ [13].

$$
\begin{aligned}
& \mathrm{Ca}\left(\mathrm{H}_{2} \mathrm{PO}_{4}\right)_{2}+2 \mathrm{NH}_{4}^{+} \rightarrow 2 \mathrm{NH}_{4} \mathrm{H}_{2} \mathrm{PO}_{4} \\
& \mathrm{CaSO}_{4}+2 \mathrm{NH}_{4}^{+} \rightarrow\left(\mathrm{NH}_{4}\right)_{2} \mathrm{SO}_{4} \\
& 2 \mathrm{H}_{3} \mathrm{PO}_{4}+2 \mathrm{NH}_{4}^{+} \rightarrow 2 \mathrm{NH}_{4} \mathrm{H}_{2} \mathrm{PO}_{4} \\
& \mathrm{H}_{2} \mathrm{SO}_{4}+2 \mathrm{NH}_{4}^{+} \rightarrow\left(\mathrm{NH}_{4}\right)_{2} \mathrm{SO}_{4}
\end{aligned}
$$

Different proportions of $\mathrm{Mg}(\mathrm{OH})_{2}$ and $\mathrm{H}_{3} \mathrm{PO}_{4}$ were mixed to produce an emulsion that was not completely soluble in water. It was a mixture containing $\mathrm{MgHPO}_{4}$, $\mathrm{Mg}\left(\mathrm{H}_{2} \mathrm{PO}_{4}\right)_{2}, \mathrm{Mg}_{3}\left(\mathrm{PO}_{4}\right)_{2}$ and their crystalline water, which could react with ammonia:

$\mathrm{Mg}^{2+}+\mathrm{NH}_{4}{ }^{+}+\mathrm{PO}_{4}{ }^{3-}+\mathrm{H}_{2} \mathrm{O} \rightarrow \mathrm{MgNH}_{4} \mathrm{PO}_{4} \cdot 6 \mathrm{H}_{2} \mathrm{O}$ (7)

Struvite crystal $\left(\mathrm{MgNH}_{4} \mathrm{PO}_{4} \cdot 6 \mathrm{H}_{2} \mathrm{O}\right)$ was also a kind of high-quality inorganic fertilizer, which not only had a good fixation effect on ammonia, but also increased the content of $\mathrm{P}$ in the compost. Therefore, it was an ideal compost additive [14].

\subsubsection{TN}

The change of TN content in simulated composting with different treatments was shown in Fig. 4, and the TN content of the treatments with additives was significantly higher than that in the CK. More the fixative added, higher the TN content was. In the first 3 days of composting, all treatments with a ratio of $3.85 \%$ showed a downward trend, which may be due to the conversion of part of $\mathrm{NH}_{4}{ }^{+} \mathrm{N}$ into ammonia volatilization, and only a small amount of degradation of the material itself. In the treatments of $5.66 \%$ and $7.41 \%$ ratio, only the TN content of the peat decreased slightly in the first 3 days. The TN content of the compost material increased gradually with the addition ratio of $9.09 \%$, indicating that the additive had a fixation effect on the $\mathrm{N}$ of the compost material. With the progress of composting, organic matter began to degrade violently. Because of the double effects of concentration and fixation, the content of $\mathrm{TN}$ in each treatment with fixative presented an increasing trend. The peak period of ammonia generation was 4-6 days, and the rising period of TN content was less than 6-8 days generally.

At the end of the experiment, compared with the $\mathrm{CK}$, from peat to superphosphate to $\mathrm{Mg}(\mathrm{OH})_{2}+\mathrm{H}_{3} \mathrm{PO}_{4}$ treatment, the $\mathrm{TN}$ content of the fixative with the addition of $3.85 \%$ increased by $2.53 \%, 9.08 \%$ and $13.08 \%$, respectively. The addition amount of $5.66 \%$ increased by $9.40 \%$ and $18.77 \%$. The addition amount of $7.41 \%$ increased by $10.85 \%, 18.19 \%$ and $32.76 \%$, respectively. The $\mathrm{TN}$ content of $9.09 \%$ addition amount increased by $20.28 \%, 31.11 \%$ and $39.31 \%$, respectively.

Compared with different fixatives, it could be seen that no matter which amount of addition, the treatment of $\mathrm{Mg}(\mathrm{OH})_{2}+\mathrm{H}_{3} \mathrm{PO}_{4}$ had the highest TN content, followed by the treatment of superphosphate and peat. The results showed that $\mathrm{Mg}(\mathrm{OH})_{2}+\mathrm{H}_{3} \mathrm{PO}_{4}$ treatment had the best $\mathrm{N}$ fixation effect among the three fixatives. There was no significant difference between the treatment with a proportion of $3.85 \%$ additives and the control ( $p$ values were $0.475,0.212$ and 0.132 , respectively), while the difference between the other treatments and the control was significant, indicating that the $\mathrm{N}$ fixation effect on compost was limited when the dosage was low. The difference of the same additive in different proportion was extremely significant. The variance analysis between treatments with different proportions of peat was $F=5.9, p=$ $0.003 * *$ ( $\mathrm{P}$ value less than 0.01 indicates that the difference between the two groups is extremely 



Fig. 4 TN content of different treatments. (a) peat, (b) superphosphate, (c) $\mathrm{Mg}(\mathrm{OH})_{2}+\mathrm{H}_{3} \mathrm{PO}_{4}$.

A1: 3.85\% peat; A2: 5.66\% peat; A3: 7.41\% peat; A4: 9.09\% peat; B1: 3.85\% superphosphate; B2: 5.66\% superphosphate; B3: 7.41\% superphosphate; B4: $9.09 \%$ superphosphate; $\mathrm{C} 1: \quad 3.85 \% \quad \mathrm{Mg}(\mathrm{OH})_{2}+\mathrm{H}_{3} \mathrm{PO}_{4} ; \quad \mathrm{C} 2: \quad 7.41 \% \quad \mathrm{Mg}(\mathrm{OH})_{2}+\mathrm{H}_{3} \mathrm{PO}_{4} ; \quad \mathrm{C} 3: \quad 9.09 \%$ $\mathrm{Mg}(\mathrm{OH})_{2}+\mathrm{H}_{3} \mathrm{PO}_{4}$.
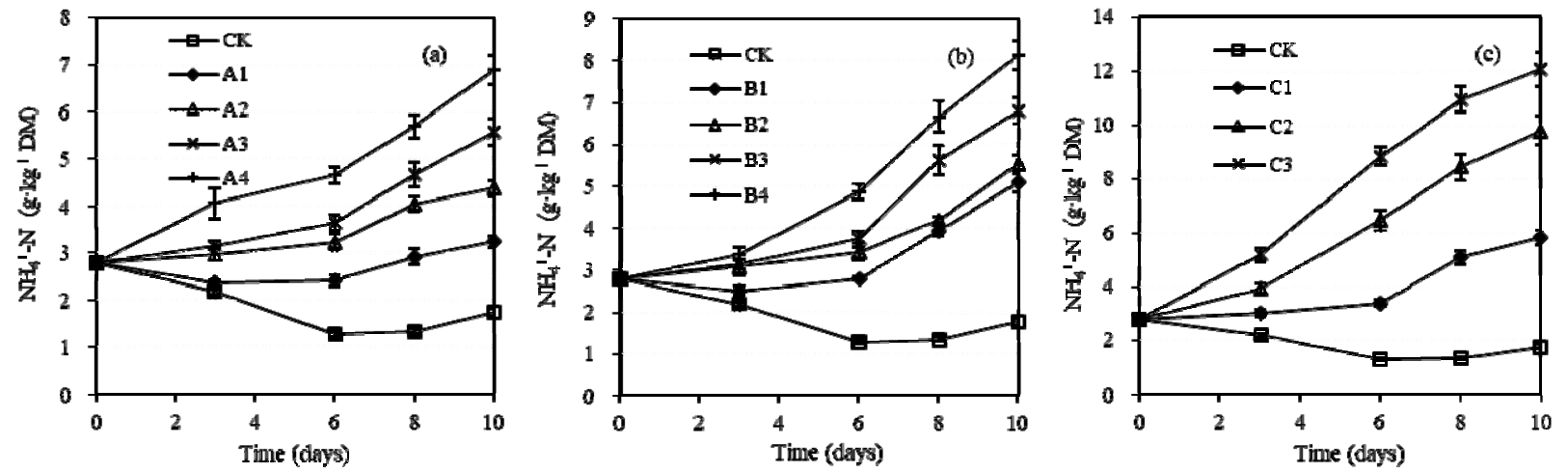

Fig. $5 \mathrm{NH}_{4}^{+}-\mathrm{N}$ changes of different treatments during simulated composting. (a) peat, (b) superphosphate, (c) $\mathrm{Mg}(\mathrm{OH})_{2}+\mathrm{H}_{3} \mathrm{PO}_{4}$.

A1: 3.85\% peat; A2: 5.66\% peat; A3: 7.41\% peat; A4: 9.09\% peat; B1: 3.85\% superphosphate; B2: 5.66\% superphosphate; B3: 7.41\% superphosphate; $\quad$ B $4: \quad 9.09 \%$ superphosphate; $\quad \mathrm{C} 1: \quad 3.85 \% \quad \mathrm{Mg}(\mathrm{OH})_{2}+\mathrm{H}_{3} \mathrm{PO}_{4} ; \quad \mathrm{C} 2: \quad 7.41 \% \quad \mathrm{Mg}(\mathrm{OH})_{2}+\mathrm{H}_{3} \mathrm{PO}_{4} ; \quad \mathrm{C} 3: \quad 9.09 \%$ $\mathrm{Mg}(\mathrm{OH})_{2}+\mathrm{H}_{3} \mathrm{PO}_{4}$.

significant, similarly hereinafter), variance analysis between superphosphate treatments was $F=4.8, p=$ $0.007^{* *}$, and $\mathrm{Mg}(\mathrm{OH})_{2}+\mathrm{H}_{3} \mathrm{PO}_{4}$ treatment was $F=6.0$, $p=0.006 * *$.

\section{$3.2 .3 \mathrm{NH}_{4}^{+}-\mathrm{N}$}

The variation trend of $\mathrm{NH}_{4}{ }^{+}-\mathrm{N}$ with three fixatives was shown in Fig. 5. In the $\mathrm{CK}$ group, $\mathrm{NH}_{4}{ }^{+} \mathrm{-N}$ showed a declining trend, from $2.78 \mathrm{~g} / \mathrm{kg} \mathrm{DM}$ at the beginning to $1.75 \mathrm{~g} / \mathrm{kg} \mathrm{DM}$, which was due to the large amount of $\mathrm{NH}_{4}{ }^{+}-\mathrm{N}$ converted into $\mathrm{NH}_{3}$ in the high temperature period. However, the $\mathrm{NH}_{4}{ }^{+}-\mathrm{N}$ was fixed in the treatments with fixatives by different principles, which showed an upward trend.
Except for the low proportion treatment of A1, due to the large ammonia volatilization in the early stage of the peat treatment, the ammonia first dropped and then rose. In addition, the other treatments showed a gradually increasing trend, and with the increase of the addition proportion, the content of $\mathrm{NH}_{4}{ }^{+}-\mathrm{N}$ also gradually increased. At the end of the experiment, four adding proportions $\mathrm{NH}_{4}{ }^{+} \mathrm{N}$ content were 3.26, 4.37, 5.57 and $6.89 \mathrm{~g} / \mathrm{kg} \mathrm{DM}, 1.8-3.9$ times of the control. ANOVA results showed that the difference among treatments was extremely significant $(F=6.7, p=$ $0.001) . \mathrm{NH}_{4}{ }^{+}-\mathrm{N}$ was fixed by reducing the $\mathrm{pH}$ value of materials and chemical reaction in the superphosphate 


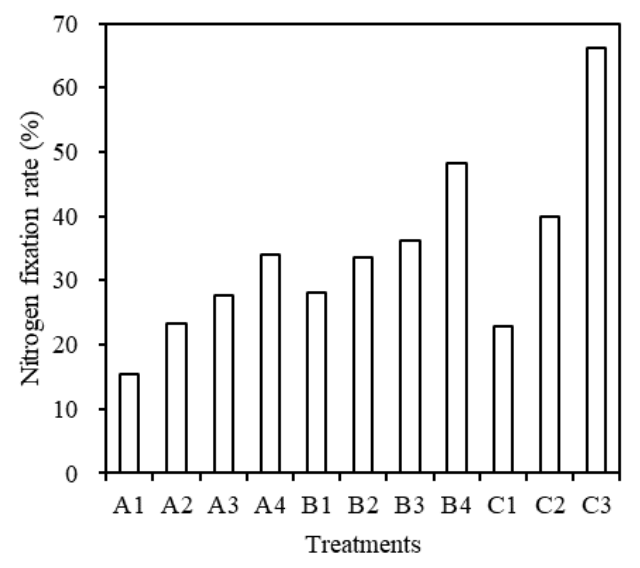

Fig. 6 Ratio of $\mathbf{N}$ fixation of different treatments.

A1: 3.85\% peat; A2: 5.66\% peat; A3: $7.41 \%$ peat; A4: $9.09 \%$ peat; B1: 3.85\% superphosphate; B2: 5.66\% superphosphate; B3: $7.41 \%$ superphosphate; $\mathrm{B} 4: 9.09 \%$ superphosphate; $\mathrm{C} 1$ : $3.85 \% \mathrm{Mg}(\mathrm{OH})_{2}+\mathrm{H}_{3} \mathrm{PO}_{4} ; \mathrm{C} 2: 7.41 \% \mathrm{Mg}(\mathrm{OH})_{2}+\mathrm{H}_{3} \mathrm{PO}_{4} ; \mathrm{C} 3$ : $9.09 \% \mathrm{Mg}(\mathrm{OH})_{2}+\mathrm{H}_{3} \mathrm{PO}_{4}$.

treatments, and the fixation effect was better than peat. At the end of the experiment, with the increase of additive proportion, the contents of $\mathrm{NH}_{4}{ }^{+} \mathrm{N}$ of superphosphate treatments were 5.09, 5.55, 6.81 and $8.13 \mathrm{~g} / \mathrm{kg} \mathrm{DM}$, respectively, which were 2.9-4.6 times higher than that of the control treatment, and the difference between treatments was significant $(F=$ $3.54, p=0.024)$.

Compared with the other two fixatives of the same proportion, $\mathrm{Mg}(\mathrm{OH})_{2}+\mathrm{H}_{3} \mathrm{PO}_{4}$ treatment had the higher $\mathrm{NH}_{4}{ }^{+}-\mathrm{N}$ content. Moreover, more the phosphoric acid added, higher the $\mathrm{NH}_{4}{ }^{+} \mathrm{N}$ content was. The analysis of variance showed that the difference between treatments was extremely significant $(F=35.38, p=$ 0.009). At the end of the test, compared with the same proportion of superphosphate treatment, the ammonia nitrogen content of the $\mathrm{Mg}(\mathrm{OH})_{2}+\mathrm{H}_{3} \mathrm{PO}_{4}$ treatment increased by $0.75,2.98$ and $3.92 \mathrm{~g} / \mathrm{kg}$ DM with the increase of the addition proportion respectively. This was because the fixing agent combined with $\mathrm{NH}_{4}{ }^{+}-\mathrm{N}$ to produce magnesium ammonium phosphate. Theoretically, this not only could control $\mathrm{N}$ loss, but also could produce a high-quality slow-release fertilizer, which was more potential than the former two.

\subsubsection{N Fixation Rate}

At the end of composting, the $\mathrm{N}$ loss rate of the control treatment was $55.72 \%$. The change of $\mathrm{N}$ fixation rate of different treatments was shown in Fig. 6 . As could be seen from the figure, the $\mathrm{N}$ fixation rate of each additive treatment increased with the increase of the additive. In addition to $\mathrm{C} 1$ treatment, among the treatments with the same addition ratio, the treatment of $\mathrm{Mg}(\mathrm{OH})_{2}+\mathrm{H}_{3} \mathrm{PO}_{4}$ showed the best $\mathrm{N}$ fixation effect, and the treatment with the $9.09 \%$ amount of the addition had the highest $\mathrm{N}$ fixation rate (being up to $66 \%$ ), followed by superphosphate and peat treatment.

\section{Conclusions}

Under the same simulated composting conditions, the $\mathrm{N}$ fixation effect of the three kinds of fixatives with the same proportion was as follows: $\mathrm{Mg}(\mathrm{OH})_{2}+\mathrm{H}_{3} \mathrm{PO}_{4}>$ superphosphate $>$ peat. Furthermore, within a certain range, the fixation effect of $\mathrm{N}$ increased with the increase of the additive. The $\mathrm{N}$ fixation rate of $\mathrm{Mg}(\mathrm{OH})_{2}+\mathrm{H}_{3} \mathrm{PO}_{4}$ treatment was up to $66 \%$. Compared with the CK, the amount of cumulative ammonia volatilization decreased by $90.3 \%$ and the TN content increased by $39.31 \%$ of this treatment. Compared with other two kinds of fixing agents, $\mathrm{Mg}(\mathrm{OH})_{2}+\mathrm{H}_{3} \mathrm{PO}_{4}$ could not only control $\mathrm{N}$ loss in composting process, improve the $\mathrm{N}$ nutrient content of compost, but also could increase $\mathrm{P}$ and $\mathrm{Mg}$ nutrients. Therefore, it had more popularization value and application prospect.

\section{References}

[1] Yang, F., Li, G., and Shi, H. 2015. "Effects of Phosphogypsum and Superphosphate on Compost Maturity and Gaseous Emissions during Kitchen Waste Composting." Waste Management 36: 70-6.

[2] Petersen, S. O., and Sommer, S. G. 2011. "Ammonia and Nitrous Oxide Interactions: Roles of Manure Organic Matter Management." Animal Feed Science and Technology 166 (1): 503-13.

[3] Li, X., Wang, Y., and Guo, X. 2013. "Seasonal Variation and Source Apportionment of Organic and Inorganic Compounds in $\mathrm{PM}_{2.5}$ and $\mathrm{PM}_{10}$ Particulates in Beijing, 
China.” Journal of Environmental Sciences-China 25 (4): 741-50.

[4] Guo, R., Li, G., and Jiang, T. 2012. "Effect of Aeration Rate, $\mathrm{C} / \mathrm{N}$ Ratio and Moisture Content on the Stability and Maturity of Compost." Bioresource Technology 112: 171-8.

[5] Fukumoto, Y., Suzuki, K., Kuroda, K., Waki, M., and Yasuda, T. 2011. "Effects of Struvite Formation and Nitratation Promotion on Nitrogenous Emissions such as $\mathrm{NH}_{3}, \mathrm{~N}_{2} \mathrm{O}$ and NO during Swine Manure Composting." Bioresource Technology 102: 1468-74.

[6] Kataki, S., West, H., Clarke, M., and Baruah, D. C. 2016. "Phosphorus Recovery as Struvite: Recent Concerns for Use of Seed, Alternative Mg Source, Nitrogen Conservation and Fertilizer Potential." Resources Conservation and Recycling 107: 142-56.

[7] Wang, X., Selvam, A., and Wong, J. W. 2016. "Influence of Lime on Struvite Formation and Nitrogen Conservation during Food Waste Composting." Bioresource Technology 217: 227-32.

[8] Wang, X., Selvam, A., and Chan, M. 2013. "Nitrogen Conservation and Acidity Control during Food Wastes Composting through Struvite Formation.” Bioresource Technology 147: 17-22.

[9] Liu, L., Kong, H., and Lu, B. 2015. "The Use of
Concentrated Monosodium Glutamate Wastewater as a Conditioning Agent for Adjusting Acidity and Minimizing Ammonia Volatilization in Livestock Manure Composting." Journal of Environmental Management 161: 131-6.

[10] Kurola, J. M., Arnold, M., and Kontro, M. H. 2010. "Effect of Light Sphagnum Peat on Odour Formation in the Early Stages of Biowaste Composting." Waste Management 30 (5): 779-86.

[11] Zhang, J., Lu, F., and Shao, L. 2014. "The Use of Biochar-Amended Composting to Improve the Humification and Degradation of Sewage Sludge." Bioresource Technology 168: 252-8.

[12] Luo, Y., Li, G., and Frank, S. 2012. "Effects of Additive Superphosphate on $\mathrm{NH}_{3}, \mathrm{~N}_{2} \mathrm{O}$ and $\mathrm{CH}_{4}$ Emissions during Pig Manure Composting." Transactions of the Chinese Society of Agricultural Engineering 28 (22): 235-42.

[13] Jiang, T., Ma, X., and Yang, J. 2016. "Effect of Different Struvite Crystallization Methods on Gaseous Emission and the Comprehensive Comparison during the Composting." Bioresource Technology 217: 219-26.

[14] Jiang, T., Ma, X., and Tang, Q. 2016. "Combined Use of Nitrification Inhibitor and Struvite Crystallization to Reduce the $\mathrm{NH}_{3}$ and $\mathrm{N}_{2} \mathrm{O}$ Emissions during Composting." Bioresource Technology 217: 210-8 